\title{
Перспективные гетероструктуры на основе АзВ5 полупроводников для фотоприемников ближнего и среднего ИК диапазонов спектра
}

\author{
к.С. Журавлев ${ }^{1}$, А.С. Башкатов ${ }^{2}$, О.Н. Морозова ${ }^{2}$ \\ ${ }^{1}$ Институт Физики Полупроводников им. А.В. Ржанова, Новосибирск, \\ 630090, пр-т Академика Лаврентьева, 13 \\ тел:+7 (383) 330-4475, факс:+7 (383) 330-6945, эл.nочта: zhur@isp.nsc.ru \\ ${ }^{2}$ ФГУП «МНИИРИП», Мытищи, \\ 13141002, Московская область, г. Мытищи, ул. Колпакова, д. 2 a \\ тел: +7 (495) 586-17-21, факс: +7 (495) 588-69-61, эл. почта: info@ mniirip.ru
}

DOI 10.34077/RCSP2021-32

Инфракрасные фотоприемники (ИК ФП) широко применяются в различных областях, таких как ночное видение, слежение за ракетами, медицинская визуализация и визуализация дефектов в различных устройствах, электронных схемах, тепловых утечек и зондирование окружающей среды. В настоящее время доминируют ИК ФП на основе теллурида кадмия и ртути и материалов $\mathrm{A}_{3} \mathrm{~B}_{5}$, технология роста которых хорошо развита. В последние несколько десятилетий значительное усилия были направлены на повышение эффективности и повышение рабочей температуры ИК ФП, снижение стоимости изготовления, упрощение процессов изготовления, увеличивающие выход продукции, за счет использования достижения в области нанотехнологий. В данном докладе рассматриваются современные гетероструктуры на основе $\mathrm{A}_{3} \mathrm{~B}_{5}$ материалов для ИК ФП ближневолновой (SWIR) от 0,8 до 3 мкм и средневолновой (MWIR) от 3 до 5 мкм ИК-областей спектра. SWIR область важна для телекоммуникаций и радиофотоники, поскольку низкие потери в оптических волокнах позволяет передавать информацию без значительных потерь; MWIR область прежде всего важна для мониторинга окружающего пространства, космической связи и астрономии из-за высокой прозрачность атмосферы на этих длинах волн.

После демонстрации в начале 1960-х годов первых ИК ФП на основе слоев узкозонных InSb полупроводников их характеристики значительно улучшились, а области применения расширились. Развитие методов очистки материалов и технологии эпитаксиального выращивания гетероструктур позволили расширить ряд используемых материалов, широко применять методы зонной инженерии для получения ИК ФП с улучшенными характеристиками. В настоящее время при росте гетероструктур используются бинарные соединения InSb, InAs, InSb и многокомпонентные твердые растворы InGaAs и InAsSb; активно применяются и разрабатываются низкоразмерные гетероструктуры с нанометровыми барьерами, с квантовыми ямами, квантовыми точками, сверхрешетками и нанопроволоками. Для увеличении связи света с электронные состояниями поглощающего материала, повышения чувствительности ИК ФП широко исследуются возможности наноструктур в качестве просветляющих покрытий, оптических антенн, плазмонных структур и метаматериалов. Твердый раствор $\operatorname{In}_{0,53} \mathrm{Ga}_{0,47} \mathrm{As}\left(\mathrm{E}_{\mathrm{g}}=0,73\right.$ эB), согласованный с $\mathrm{InP}$ подложкой, является наиболее подходящим материалом для детекторов спектрального диапазона 1.0-1.7 мкм. ФП на его основе имеют высокую чувствительность, низкий темновой ток и шум. Чувствительность ФП можно максимизировать на желаемой длине волны, создать гетероструктуры с усилением света за счет электронной инжекции или лавинного усиления. Активно развиваются конструкции гетероструктур для малошумящих лавинных ФП. Еще один материал из семейства III - V, который выделяется на фоне других материалов для ИК ФП - InAsSb. Этот тройной раствор, более устойчив по сравнению с $\mathrm{HgCdTe}$, имеет низкий коэффициент самодиффузии, довольно слабую зависимость между шириной запрещенной зоны и составом и малую диэлектрическую проницаемость, обеспечивающую более короткое время диэлектрической релаксации и меньшая емкость. На его основе создаются короткопериодные сверхрешетки второго рода, характеристики которых значительно улучшены в последнее время за счет введения блокирующего слоя с большей шириной запрещенной зоны чем окружающие слои сверхрешетки. Стремление более высоких рабочих температур, более высокой эффективности и более низкой стоимости ИК ФП стимулировали поиск гетероструктур с меньшая квантовой размерностью. Большие надежды возлагались на нуль-мерные структуры. В настоящее время активно исследуются возможности нанопроволок. Рассматривается три типа фотоприемников: фотопроводники, фототранзисторы и гетероструктурные фотодиоды на основе InAs, InGaAs, InPAs и InGaSb нанопроволок. В докладе анализируются достоинства и недостатки продемонстрированных приборов, включая самые многообещающие фотоприемники на основе нанопроволок с лавинным умножением. Кроме того в докладе рассматриваются новые нанотехнологические приемы, позволяющие усилить взаимодействие света с электронной системой гетероструктур. 